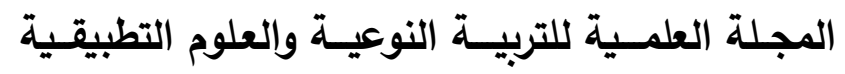

The Scientific Journal of Specific Education and Applied Sciences

\title{
Effects of adding some less-used green vegetable leaves on sensory and physico-chemical properties of low fat meatballs
}

\section{Rasha M. Arafa}

Department of Home Economics, Faculty of Specific Education, Damietta University, Egypt.

Abstract: This study aims to investigate the effect of adding green leafy vegetable mixture GLVM on the physical, chemical and sensory properties of producing low-fat meatball. Four different concentrations 2.5, 5, 10 and 15\% of GLVM were added as a substitution for meat fat. The obtained results revealed that the chemical composition showed that GLVM contains $7.3 \%$ moisture, $29.9 \%$ total protein, $3.45 \%$ crude fat, $14.6 \%$ ash and $8.43 \%$ crude fiber. Mineral composition were $45.61 \% \mathrm{Fe}, 6.65 \%$ $\mathrm{Ca}, 2.71 \% \mathrm{Zn}, 10.39 \% \mathrm{~K}$ and $0.46 \% \mathrm{Mg}$. Results indicated that the moisture, crude fiber, ash and carbohydrates content increased in meatballs prepared with GLVM compared with control sample, while the content of total protein and crud fat reduced with increasing GLVM . The ratios of USFAs / SFAs and n-6/n-3 improved gradually from 1.001 and 4.85 to 1.230 and 2.10 with increasing GLVM, respectively. Furthermore, the percentage of the total energy values and fat calories declined in all samples, while the amount of meatballs in grams consumed to cover the daily requirements for energy and protein increased in all samples as compared with the control. Meatball blends which prepared with $2.5,5,10$ and $15 \%$ GLVM showed a significant $(\mathrm{p} \leq 0.05)$ increase in the cooking yield and moisture retention\% as compared to the control. Texture properties of meatballs were affected, the hardness, cohesiveness and chewiness values were in the range of $2.793-4.887,0.595-0.656$ and $1.132-2.122$, respectively. Also, sensory evaluation results showed that product of meatballs could be easily accepted to consumers by portion up to $10 \%$. In conclusion, the study confirm the possibility of adding a green leafy vegetable mixture from turnips, beetroots and carrots to produce low-fat meatballs that can reduce heart disease and atherosclerosis. 


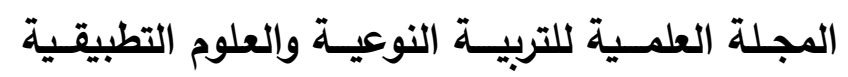

The Scientific Journal of Specific Education and Applied Sciences

Key Words: meatballs - turnip leaves - beetroot leaves - carrot leaves - Fatty acids profile - Sensory characteristics - cooking yield.

\section{Introduction}

Meat is regarded as a good source of high biological value protein, and also contains many beneficial nutrients (Reddy et al., 2018). However, WHO International Agency for Research on Cancer has classified the consumption of red meat as carcinogenic to humans (Serdaroğlu et al., 2018). As consumers have become more conscious of their health, foods including meat products with reductions levels in fat, cholesterol, salt and nitrite as well as improved fatty acid profile and incorporation of bioactive compounds has become more popular (Hur et al., 2009; Kumar et al., 2011, Biswas et al., 2011 and Beriain et al., 2018). Numerous fruits and vegetables produce at least 25 to 30 percent of waste products including skin, pulp, seeds, stones, pomace, leaves, roots, stalks, etc. (Ajila and Prasada Rao, 2013). Vegetables production and processing causes a large amount of by-products, obtaining losses of up to $75 \%$ of the harvested material in some cases (Kabir et al., 2015). The leaves of crops cultivated for the consumption of their roots (i.e. carrots, beets, turnips) are usually discarded as waste during harvest. Traditionally, these by-products have been retrieved as feed for livestock or composting (Fernández et al., 2017). Many studies indicated that vegetable by-products are containing bioactive compounds such as vitamins, enzymes (Sagar et al., 2018), dietary fibers, antioxidants, essential fatty acids, antimicrobials, among others (Farvin et al., 2012, O'Shea et al., 2012 and Kabir et al., 2015). That which promotes the immune system, helps to decrease weight and reduces the risk of CVD, cancers growth, hyperglycemia, gastrointestinal disorders (Anderson et al., 2009). Consequently, edible leaves could be consumed in order to decrease food waste, reduce production costs and to improve the technological and nutritional quality of the products.

One of the oldest grown vegetables is Brassica rapa, it is a plant composed of different subspecies, including the turnip which belonged to the cruciferous vegetable family, as are kale and broccoli. It is consumed in huge amounts worldwide because of its nutritional benefits and its usefulness in the manufacturing of edible oils (Liang et al., 2006). Usually roots are used in 


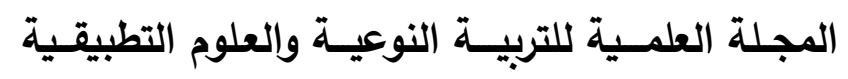

The Scientific Journal of Specific Education and Applied Sciences

making pickles. Turnip leaves are generally light green, slightly pubescent and thin. At the base of the leaf petioles grows a whitefleshed, big worldwide or tapered root. It also produces branched flowering stems. The flowers are clustered at the top of the raceme and are typically raised above the terminal buds (Fernandes et al., 2007). Turnip tops are rich sources of nutritive and bioactive substances including calcium, manganese, folate and the vitamins $\mathrm{A}, \mathrm{C}$ and $\mathrm{K}$. They are high in protein, carotenoids, chlorophylls, glucosinolates (Artemyeva et al., 2006). They also have a high content of polyphenols (from 107 to $191 \mathrm{mg} / 100 \mathrm{~g}$, fresh weight) and flavonoids like isorhamnetin, kaempferol and quercetin glycosides (Romani et al., 2006). Brassica leaves enhanced the antidiabetic (Lim et al., 2006 and Fard et al., 2015), anti-inflammatory, anticancer and antioxidant defense leading to the protection of cardiovascular diseases (Berdja et al., 2016).

Red beet (Beta vulgaris L.) is used as food all over the world, it is belong to the family Chenopodiaceae, it is common called red beet or beetroot, Beetroot is annual crop, biennial herbaceous and cultivated for their edible roots and leaves (Neelwarne and Halagur, 2012). The roots are used in making salads, jam, soups and juice (Guldiken et al., 2016). Traditionally, Beet leaves have been eaten as a green vegetable and used medicinally. Recently, many studies reported that Leaves of beetroot are a wonderful source of fiber, protein (Kapadia and Rao, 2013), potassium, calcium, iron, vitamin A (beta-carotene), vitamin $\mathrm{C}$, and folate (Neelwarne and Halagur, 2012), Beet greens also contain omega-3 fatty acids that play an significant role as structural membrane lipids, especially in nerve tissue and retina, and are eicosanoid precursors (Biondo et al., 2014). On the other hand, beet greens contain a large amount of antioxidant such as betalains; betalains comprise betacyanins (redviolet pigments) and betazanthins (yellow pigments) that could act as reactive oxygen species (ROS) scavengers, restricting bacterial infection damage and possibly contributes to reduced risk of developing chronic diseases (Lee et al., 2009). Additionally, the leaves and seeds of $B$. vulgaris $L$ contain flavonol glycosides, which were found to inhibit human breast and colon cancers (Ninfali et al. 2007, Gennari et al. 2011, and Kapadia and Rao, 2013), also beet greens contain lutein which contributes to eye health (Leong et al., 2018), total phenolic 


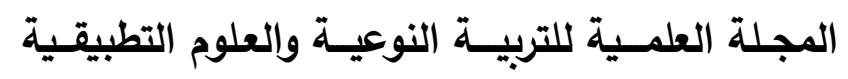

The Scientific Journal of Specific Education and Applied Sciences

compounds, mainly betacyanins (betanin and isobetanin) and ferulic acid ester [b-D-fructofuranosyla- D-(6-O-(E)feruloylglucopyranoside)] (El-Beltagi et al., 2018).

Carrot (Daucus carota L.) belongs to the family Apiaceae (Surbhi et al., 2018). Carrots are one of the most popular vegetables worldwide, taproot of carrots are seasonally available in areas that produce carrots for human consumption (Goby and Gidenne, 2008). The carrot roots are eaten as a raw or cooked ingredient in soups, sauces, salads, stews and nutritional patterns, either alone or in combination with other vegetables. Carrots are often canned, quick frozen, dehydrated and large amounts are also consumed into infant food and juices (Elzebroek and Wind, 2008). In Egypt; carrots is available in meager for most of the part of the year, carrot roots are eaten in a variety of cuisines, especially in the preparation of salads and pickles. Carrot leaves grow twice or three pinnate; kids are leaves (lines) in lancet shape. Each plant has a rather lengthy stalk of 5-7 size. Stalks firm and dense with a smooth surface, while the edge of the leaf is soft and thin (Surbhi et al., 2018). Carrot leaves are the green leaves that grow from the top of the carrot's taproot, Leaves of carrots are sometimes wasted or used as fodder (Boroski et al., 2011). On the other hand, Habegger and Schnitzler (2000) reported that carrot leaves have higher amount of essential oils than roots. The major compounds in the leaves were $\beta$-myrcene, $\alpha$-asarone, methyl isoeugenol, $\beta$-caryophyllene, (E)- $\beta$-farnesene, limonene and sabinene. In addition, Leite et al. (2011) showed that carrot leaves are very rich in fibers, vitamin $C$ and $\beta$-carotene, and several minerals such as $\mathrm{Na}, \mathrm{P}, \mathrm{K}, \mathrm{Ca}, \mathrm{Mg}, \mathrm{Mn}, \mathrm{Zn}$ and $\mathrm{Fe}$. Stephen and Suresh (2015) indicated that extracts of carrot leaves and peel were recorded to be antioxidant, while carrot flesh was inactive. On the other hand, carotenoid helps prevent cancer, cardiovascular disease, stroke and cataracts. Carrot leaves can be used to slow the process of aging. Therefore, in the present study we will try to open new avenue for extending the using of green leafy vegetables as by-product from turnips, beetroots and carrots through incorporating them in meatballs processing and evaluate its effect on physico-chemical and sensory characteristics on the meatballs; for enhancing meat products' biofunctionality and managing environmental issues. 


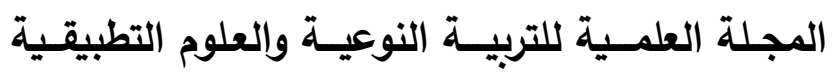

The Scientific Journal of Specific Education and Applied Sciences

\section{Materials and Methods \\ Materials}

-The leaves of selected vegetables, turnip (Brassica rapa), beet root (Beta vulgaris L.) and carrot (Daucus carota L.) were collected from Damietta Governorate, Egypt.

- Fresh lean beef meat and beef back fat were purchased from the local market from Damietta Governorate, Egypt.

\section{Methods}

\section{Preparation of green leafy vegetables:}

The green leafy vegetables from turnip, beet root and carrot were thoroughly washed separate in water 2:3 times to remove the adhering dust and impurities and blanched for $2 \mathrm{~min}$ by immersing them in boiling water, cooled and dried at $50^{\circ} \mathrm{C}$ by using an air-oven till they turned crisp and brittle to touch. The leaves were turned to a powders by using electrical blender (France Moulinex, LM 207041). The powders were then mixed together in a definite proportion of $1: 1: 1$ and stored at room temperature until using in preparation meatball formulas. The composition of $100 \mathrm{~g}$ green leafy vegetables mixture GLVM is given in Table (2). The samples were then subjected to chemical analysis.

\section{Preparation of Low fat meatball}

Lean meat and fat were ground together through a $2 \mathrm{~mm}$ plate grinder. The ground meat was packed in plastic bags and stored at $\left(-20^{\circ} \mathrm{C}\right)$ for use within $24 \mathrm{~h}$. Five formulas of meatballs were manufactured in this study according to the method as described by Yilmaz (2004) with some modification; the low fat control formula was prepared as follows in Table (1). Meanwhile, the other experimental formulations were prepared by replacing an equal amount of meat with leafy green vegetables mixture $\operatorname{GLVM}(2.5 \%, 5 \%, 10 \%$ and $15 \%)$. Additional ingredients were added to the formulas as follows; $5 \%$ bread crumb, $10 \%$ water, $2 \%$ salt, 3\% seasoning powder (Black pepper, cumin, onion, garlic, cinnamon and nutmeg). Meatball doughs were mixed for $15 \mathrm{~min}$ by hand and stored in a fridge $\left(-4^{\circ} \mathrm{C}\right)$ for two hours, then shaped into $2 \mathrm{~cm}$ diameters meatballs with a weight of $20 \mathrm{~g}$ before cooking. Meatball samples were cooked in boiling water at $\left(80^{\circ} \mathrm{C}\right)$ for $20 \mathrm{~min}$, and then samples cooled at $10^{\circ} \mathrm{C}$ for $10 \mathrm{~min}$. Next, 


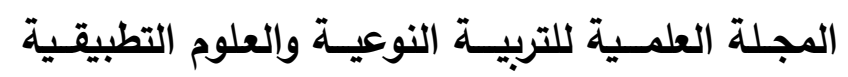

The Scientific Journal of Specific Education and Applied Sciences

meatballs put in plastic box, and frozen at $\left(-18^{\circ} \mathrm{C}\right)$ until further physical and chemical analysis.

Table (I): Meatball formula

\begin{tabular}{l|c}
\hline Ingredients & Weight $\mathbf{( \% )}$ \\
\hline Meat beef & 70 \\
\hline Beef Fat & 10 \\
\hline Bread crumb & 5 \\
\hline Water & 10 \\
\hline Salt & 2 \\
\hline Seasoning & 3 \\
\hline Total & 100 \\
\hline
\end{tabular}

\section{Determination of chemical composition}

Green leafy vegetables mixture was analyzed for moisture, ash, protein, crude fiber and fat contents, while total carbohydrates were calculated by difference as following according to AOAC (2016). Minerals content; Calcium (Ca), Iron $(\mathrm{Fe})$, Zinc $(\mathrm{Zn})$, Potassium $(\mathrm{K})$ and Magnesium $(\mathrm{Mg})$ were determined in mixture leaves according to AOAC (2000). A samples were taken from the same meatball that were used for the texture characteristics; the proximate chemical composition of meatball samples were determined; moisture, total protein, crude fat, crude fiber and ash by the AOAC (2016). The fatty acid profile was analyzed according to AOAC (2000), Fatty acid was expressed as a percentage relative to the total fatty acids.

\section{Nutritional evaluation}

Total energy value: total energy value (Kcal/100g) was calculated as follows:

Total energy value $=($ Protein $\%+$ carbohydrate $\%) \times 4+$ fat $\% \times$ 9

Fat calories: the percentage of calories related to the calories intake for each blend was calculated as follows:

$$
\% \text { Fat calories = }=\frac{\text { Calories of fat }}{-----------------\times 100}
$$




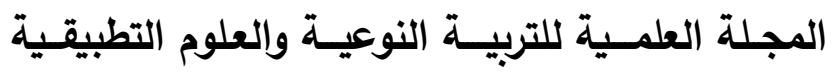

The Scientific Journal of Specific Education and Applied Sciences

The amount of meatballs in grams consumed to cover the daily requirements (GDR) for male children (11-14 years) in protein $(45 \mathrm{~g})$ and in energy $(2500 \mathrm{kcal})$; adult man $(25-50$ years $)$ in protein $(63 \mathrm{~g})$ and in energy $(2900 \mathrm{kcal})$ were calculated by using RDA (NRC, 1989). The GDR of protein and energy were calculated using the equation given by FAO/ WHO/ UNU (1985).

$\operatorname{GDR}$ of protein $(\mathrm{g})=\frac{\text { Protein daily requirements }(\mathrm{g} / \mathrm{day})}{\mathrm{Protein} \text { content }(\mathrm{g} / 100 \mathrm{~g} \text { food })} \times 100$

Energy daily requirements (kcal / day)

GDR of Energy $(\mathrm{Kcal})=$

Energy value (Kcal / $100 \mathrm{~g}$ food)

\section{Cooking yield and moisture retention}

All cooking measurements were done on five replicates per treatment. Percent cooking yield was determined by calculating weight differences for samples before and after cooking, according to the following equation from Serdaroglu (2006).

Cooking yield $(\%)=\frac{\text { Cooked meatball weight }}{\text { Uncooked meatball weight }} \times 100$

Moisture retention was calculated according to following equation from El-Magoli et al. (1996).

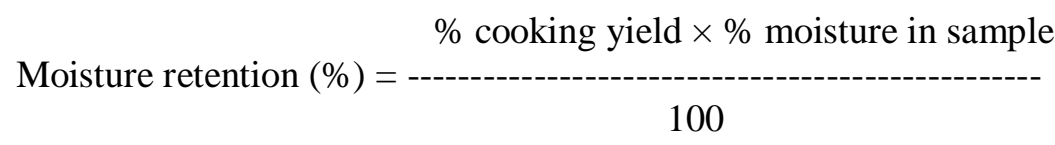

\section{Texture profile analysis:}

Samples texture measurements were carried out with universal testing machine (Cometech, B type, Taiwan). Provided with software $35 \mathrm{~mm}$ diameter compression disc was used. Two cycles were applied, at a constant crosshead velocity of $1 \mathrm{~mm} / \mathrm{s}$, to $30 \%$ of sample height, then returned. From the resulting forcetime curve, the values for texture attributes, i.e. hardness $(\mathrm{N})$, gumminess $(\mathrm{N})$, chewiness $(\mathrm{N})$, cohesiveness ratio and 


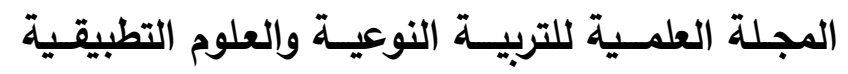

The Scientific Journal of Specific Education and Applied Sciences

springiness $(\mathrm{mm})$ were calculated from the TPA graphic (Bourne, 2003)

\section{Sensory analysis}

Meatball samples were cooled for 1-2 $\mathrm{h}$ at room temperature $\left(25 \pm 3^{\circ} \mathrm{C}\right)$ and then served in random order to a 20 panelists of staff members and students from Damietta University, Damietta, Egypt. Sensory attributes for color, taste, flavor, texture, appearance and acceptance were evaluated using a 9 - point hedonic scale $(1=$ dislike extremely to $9=$ like extremely) (IFT, 1981). Water and bread served for cleaning the mouth between samples.

\section{Statistical analysis}

Data obtained were statistically analyzed by SPSS computer software SPSS 2000. The results were expressed as mean \pm standard deviation (SD) and tested for significance using one way analysis of variance ANOVA test, according to (Armitage and Berry, 1987).

\section{Results and Discussion}

\section{Chemical composition of green leafy vegetables mixture}

Edible leaves are the manufacturing parts of the plant; they have a high in valuable constituents. But; many leaves of local vegetable are unused because of inadequate scientific knowledge of their nutritional values. Data in Table (2) presented the chemical composition of green leafy vegetables mixture (GLVM). Moisture, total protein, crude fat, ash, crude fiber and carbohydrate were receded 7.3, 29.9, 3.45, 14.6, 8.43 and 36.32\%, respectively. The content of some important minerals in GLVM were $45.61,6.65,2.71,10.39$ and $0.46 \mathrm{mg} / 100 \mathrm{~g}$ for iron, calcium, zinc, potassium and magnesium, respectively. Biondo et al. (2014) indicated that after dehydration, the leaf constituents were concentrated thus increasing the values of ashes, crude protein, total lipid, carbohydrate, and energy as compared to those of in nature leaves. Finding by Artemyeva et al. (2006) found that brassica greens are high in water, low in calories and high in protein, carbohydrates, fiber, vitamins and minerals. Also, ElShehawy et al. (2011) findings showed that carrot leaves could be regarded as a source of carbohydrates, protein and contained a complete phenols. Furthermore, Biondo et al. (2014) reported 


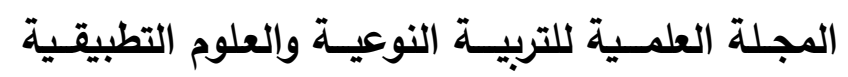

The Scientific Journal of Specific Education and Applied Sciences

that dehydrated beetroot leaves provided a healthy source of protein, free of cholesterol, elevated in dietary fiber and had a substantial antioxidant activity and quantities of total phenolic compounds, macro- and micro minerals.

\section{Table (2): Gross chemical composition of green leafy vegetables mixture (\% dry weight basis)}

\begin{tabular}{l|c}
\hline Components & Ingredients \\
\hline Moisture $(\mathrm{g})$ & $7.3 \pm 0.21$ \\
\hline $\begin{array}{l}\text { Total Protein } \\
(\mathrm{g})\end{array}$ & $29.9 \pm 0.46$ \\
\hline Crude Fat $(\mathrm{g})$ & $3.45 \pm 0.08$ \\
\hline Ash $(\mathrm{g})$ & $14.6 \pm 0.18$ \\
\hline Crude fiber $(\mathrm{g})$ & $8.43 \pm 0.4$ \\
\hline $\begin{array}{l}\text { Carbohydrate } \\
(\mathrm{g})\end{array}$ & $36.32 \pm 0.27$ \\
\hline $\mathrm{Fe}(\mathrm{mg})$ & $45.61 \pm 0.00$ \\
\hline $\mathrm{Ca}(\mathrm{mg})$ & $6.65 \pm 0.00$ \\
\hline $\mathrm{Zn}(\mathrm{mg})$ & $2.71 \pm 0.00$ \\
\hline $\mathrm{K}(\mathrm{mg})$ & $10.39 \pm 0.00$ \\
\hline $\mathrm{Mg}(\mathrm{mg})$ & 0.46 \\
\hline
\end{tabular}

Each value represents the mean \pm SD.

Due to human different body functions, macro minerals $\mathrm{Ca}$ and $\mathrm{Mg}$ in the formation of bones, teeth, and tissues, mineral elements are important in their diet. $\mathrm{Fe}$ is a component of the hemoglobin molecule, which is essential for the transport of oxygen and cell breathing. These elements can be found in cereal, fruit and vegetable roots and leaves (Kawashima and Soares, 2003 and Ekholm et al., 2007). Leafy green vegetables are rich in phenolic compounds with a wide range of biological functions, including antioxidants and antimicrobial activity (Kim et al., 2013). It is assumed that the combination of antioxidants and hytochemicals found in vegetables may improve health by inhibiting the formation of free radicals responsible for early stage development of some chronic diseases (Kumar, 2017). Study by Walsh et al. (2015) reported that carotenoids such as Lutein and zeaxanthin which that are selectively absorbed into the eye's macula, are found to have the highest concentrations in dark green leafy vegetables. 


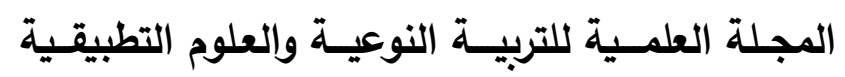

The Scientific Journal of Specific Education and Applied Sciences

\section{Chemical composition of prepared meatballs with GLVM}

The chemical composition of meatballs supplemented with green leafy vegetables mixture GLVM in this investigation presented in Table (3). Results observed that control sample containing $16.10 \%$ moisture, $52.91 \%$ total protein, $16.61 \%$ crude fat, $0.58 \%$ crude fiber, $4.55 \%$ ash and $9.25 \%$ carbohydrates. Addition of GLVM with different levels 2.5, 5, 10 and $15 \%$ had given raise to moisture content of meatball samples from 16.50 to 19.70 as compare to the control. It well be recognized that the most effective method in lowering calorie is to reduce the fat content in meat products. Results indicated that substitution of meat with green leafy vegetables mixture caused a reduction in the crude fat content from 15.46 to $13.26 \%$ as compared to the control samples, similar results were obtained by Yılmaz (2005) who found that the highest fat content was obtained from the control meatballs and the values of all samples produced with wheat bran were the lowest. As well as, the same levels from GLVM caused a slight decreasing in the total protein content from 51.32 to 43.75 , as compared to the control samples. The carbohydrate content showed an increase with a decrease in the protein content. Also, carbohydrate content in samples increased with increasing amount of GLVM, they were recorded 9.92, $11.75,11.57$ and $12.26 \%$ respectively. On the other hand, it has been reported that consumption of fiber helps with decreased cholesterol levels and the absorption of glucose, decreased incidence of hemor-rhoids and colon cancer (Gedikoğlu and Clarke, 2019). Data in table (3) revealed that there was an extremely increased in crude fiber content for meatballs supplemented with GLVM by about 3.2, 4.3, 5.7 and 6.7 times, respectively as compared to the control sample. As expected, adding GLVM with different ratios to meatballs induced improvement on ash content from 4.95 to $7.14 \%$, as compared to the control sample. Which means that green leafy vegetables mixture GLVM improved dietary fiber and ash in meatballs. In this respect, Laban (2004) revealed that moisture, ash and fiber contents were substantially higher in beef burger formulated with pomegranate peels and lower in fat than in control. Furthermore, Bessar (2008) declared that the high level of fiber in burger can be useful in decreasing cholesterol level in human body. 


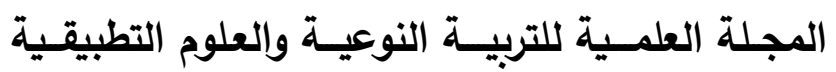

The Scientific Journal of Specific Education and Applied Sciences

\section{Table (3): Chemical composition of prepared meatballs with GLVM (\% dry weight basis)}

\begin{tabular}{c|c|c|c|c|c}
\hline \multirow{2}{*}{ Component \% } & \multirow{2}{*}{$\begin{array}{c}\text { Control } \\
\mathbf{0 \%}\end{array}$} & \multicolumn{4}{|c}{ Meatball with GLVM\% } \\
\cline { 3 - 6 } & & $\mathbf{2 . 5 \%}$ & $\mathbf{5 \%}$ & $\mathbf{1 0 \%}$ & $\mathbf{1 5 \%}$ \\
\hline \multirow{2}{*}{ Moisture } & 16.10 & 16.50 & 17.00 & 19.10 & 19.70 \\
& \pm 0.29 & \pm 0.35 & \pm 0.28 & \pm 0.21 & \pm 0.14 \\
\hline \multirow{2}{*}{ Total Protein } & 52.91 & 51.32 & 48.64 & 46.12 & 43.75 \\
& \pm 0.84 & \pm 0.69 & \pm 0.42 & \pm 0.43 & \pm 0.37 \\
\hline \multirow{2}{*}{ Crude Fat } & 16.61 & 15.46 & 14.75 & 13.90 & 13.26 \\
& \pm 0.74 & \pm 0.81 & \pm 0.60 & \pm 0.54 & \pm 0.31 \\
\hline \multirow{2}{*}{ Crude Fiber } & 0.58 & 1.85 & 2.47 & 3.30 & 3.89 \\
& \pm 0.11 & \pm 0.24 & \pm 0.21 & \pm 0.19 & \pm 0.26 \\
\hline \multirow{2}{*}{ Ash } & 4.55 & 4.95 & 5.39 & 6.01 & 7.14 \\
& \pm 0.00 & \pm 0.00 & \pm 0.00 & \pm 0.00 & \pm 0.00 \\
\hline \multirow{2}{*}{ Carbohydrates } & 9.25 & 9.92 & 11.75 & 11.57 & 12.26 \\
& \pm 0.73 & \pm 0.61 & \pm 0.49 & \pm 0.54 & \pm 0.46 \\
\hline
\end{tabular}

Each value represents the mean \pm SD.

\section{Fatty acid profile of prepared meatballs with GLVM}

Finding in Table (4) presented the fatty acid composition of prepared meatballs with adding green leafy vegetables mixture GLVM (mg/100g). Many epidemiological and clinical studies have documented the nutritional benefits of unsaturated fatty acids. Wang and Hu (2017) indicated that if SFAs are replaced by unsaturated fats, particularly polyunsaturated fatty acids, a significant reduction in CVD risk can be achieved. Results observed that total USFAs contents increased with more GLVE addition in meatball samples, they recorded 50.02, 52.13, 53.29 and $55.16 \mathrm{mg} / 100 \mathrm{~g}$, respectively. While, the lowest amount of total USFAs was found in the control sample $47.83 \mathrm{mg} / 100 \mathrm{~g}$. On the other hand, the ratio of total unsaturated fatty acids to total saturated fatty acids USFAs / SFAs was 1.001, 1.089, 1.141 and $1.230 \mathrm{mg} / 100$ respectively, in the meatball samples enhanced with different ratios from GLVM. Whereas, the control sample recorded $0.916 \mathrm{mg} / 100 \mathrm{~g}$. These results in agreement with those by Yilmaz and Daglioglu (2003) who indicated that oat bran added meatballs showed higher content of oleic and linoleic acid. Total USFA increased and SFA decreased significantly as the level of oat bran in meatballs increased. Yilmaz (2004) who observed that 


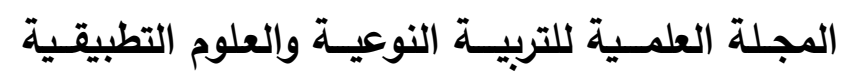

The Scientific Journal of Specific Education and Applied Sciences

the ratio of total USFA to SFA varied between 1.01 and 1.07 in the rye bran added (5-20\% levels) samples, there was significant increase in total polyunsaturated fatty acids in rye bran added meatballs. Yılmaz (2005) who found a significant difference between amounts of total unsaturated fatty acids of wheat bran added in meatball samples and the control, thereby improving the ratio of total unsaturated fatty acids to total saturated fatty acids.

Research indicates that an excess of omega- 6 fatty acids in our diets may promote prothrombotic and proaggregatory activity, whereas omega-3 fatty acids promote an anti-inflammatory and anti-thrombotic physiology (Simopoulos, 2006). Moreover, Wang and Hu (2017) reported that both n-6 and n-3 polyunsaturated fatty acids are essential for good health and low CVD and type 2 diabetes rates. In addition, Edelman and Colt (2016) adduced that a-linolenic acid, which is bountiful in many green leafy vegetables and is an essential source of omega-3, can metabolize in our bodies to longer chain fatty acids like docosahexaenoic acid and eicosapentaenoic acid. Consuming of these fatty acids can prevent diseases like rheumatoid arthritis, coronary diseases, colon, prostate, and brain cancer, and other chronic diseases common in western societies (Biondo et al., 2014). Data observed that incorporation of GLVM into the meatballs at the levels of 2.5, 5, 10 and $15 \%$ improved values of omega- 3 and omega- 6 fatty acids, as compare to the control samples. They were recorded 1.33, 2.09, 2.47, 3.21 and 6.45, 6.50 $7.10,6.75$ respectively, while, the control sample obtained the lowest values 0.73 and 6.16 respectively. Consequently, the amount of n-6/n-3 ratio had improved in meatball samples with increasing GLVM to be 4.85, 3.11, 3.18 and 2.10 respectively, vs 8.44 for the control samples. Generally, the high contribution of animal fat in human diets associated with high cholesterol intake is believed to be linked with the occurrence of diet-related diseases like coronary heart diseases (Mozaffarian et al., 2010). 


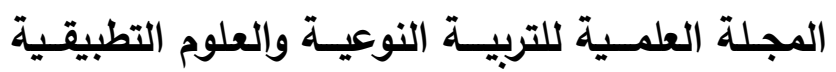

The Scientific Journal of Specific Education and Applied Sciences

\section{Table (4): Fatty acid composition of prepared meatballs with GLVM (mg/100g)}

\begin{tabular}{|c|c|c|c|c|c|}
\hline \multirow{2}{*}{ Fatty acids } & \multirow{2}{*}{$\begin{array}{l}\text { Contro } \\
10 \%\end{array}$} & \multicolumn{4}{|c|}{ Meatball with GLVM } \\
\hline & & $2.5 \%$ & $5 \%$ & $10 \%$ & $15 \%$ \\
\hline Caprlyic acid C8:0 & 0.26 & 0.25 & 0.16 & 0.12 & nil \\
\hline Capric acid C10:0 & 0.49 & Nil & Nil & Nil & nil \\
\hline Lauric acid C12:0 & 1.55 & 0.16 & 0.15 & 0.16 & 0.12 \\
\hline Myristic acid C14:0 & 3.72 & 3.04 & 3.78 & 3.65 & 3.24 \\
\hline Pentaenoic acid C15:0 & 1.35 & 1.87 & 1.05 & 0.79 & 1.0 \\
\hline Palmitic acid C16:0 & 25.11 & 25.15 & 24.02 & 23.63 & 23.15 \\
\hline Heptadecanoic acid C17:0 & 2.18 & 2.10 & 2.06 & 2.12 & 1.47 \\
\hline Stearic acid C18:0 & 17.37 & 17.25 & 16.52 & 16.11 & 15.71 \\
\hline Arachidic acid C20:0 & 0.14 & 0.16 & 0.13 & 0.13 & 0.15 \\
\hline Total SFAs & 52.17 & 49.98 & 47.87 & 46.71 & 44.84 \\
\hline Tetradecenoic acid C14:1 & 0.78 & 0.70 & 0.73 & 0.79 & 0.71 \\
\hline Palmitoleic acid C16:1 & 2.99 & 3.08 & 3.53 & 3.43 & 3.24 \\
\hline Oleic acid $\mathrm{C} 18: 1$ & 35.55 & 36.54 & 37.42 & 38.77 & 39.21 \\
\hline Eicosaenoic acid C20:1 & 0.82 & 0.88 & 0.43 & 0.38 & 0.23 \\
\hline MUSFA & 40.14 & 41.20 & 42.11 & 43.37 & 43.39 \\
\hline Hexagonic acid C16:3 & 0.56 & 0.53 & 0.61 & 0.59 & 0.51 \\
\hline C18:2 & 0.24 & 0.51 & 0.82 & 0.76 & 1.30 \\
\hline Linoleic acid C18:2 $\omega 6$ & 5.29 & 5.45 & 5.42 & 5.91 & 5.64 \\
\hline $\begin{array}{l}\text { G Linolenic acid C18:3 } \\
\omega 6\end{array}$ & 0.33 & 0.54 & 0.68 & 0.47 & 0.33 \\
\hline Linolenic acid C18:3 $\omega 3$ & 0.23 & 0.61 & 1.22 & 1.54 & 1.86 \\
\hline Stearidonic acid C18:4 $\omega 3$ & 0.50 & 0.72 & 0.87 & 0.93 & 1.35 \\
\hline $\begin{array}{l}\text { Eicosadienoic acid C20:2 } \\
\omega 6\end{array}$ & 0.31 & 0.27 & 0.23 & 0.39 & 0.33 \\
\hline $\begin{array}{l}\text { Eicosatrienoic acid C20:3 } \\
\omega 6\end{array}$ & Nil & Nil & Nil & 0.21 & 0.16 \\
\hline Arachidonic acid C20:4 $\omega 6$ & 0.23 & 0.19 & 0.17 & 0.12 & 0.29 \\
\hline PUSFA & 7.69 & 8.82 & 10.02 & 10.92 & 11.77 \\
\hline Total USFAs & 47.83 & 50.02 & 52.13 & 53.29 & 55.16 \\
\hline USFAs / SFAs & 0.916 & 1.001 & 1.089 & 1.141 & 1.230 \\
\hline Omega 3 fatty acids & 0.73 & 1.33 & 2.09 & 2.47 & 3.21 \\
\hline Omega 6 fatty acids & 6.16 & 6.45 & 6.50 & 7.10 & 6.75 \\
\hline$\omega-6 / \omega-3$ & 8.44 & 4.85 & 3.11 & 3.18 & 2.10 \\
\hline
\end{tabular}

SFAs: Saturated Fatty Acid, MUSFA: Monounsaturated Fatty Acids, PUSFA:

Polyunsaturated Fatty Acids, USFAs: Unsaturated Fatty Acids. 


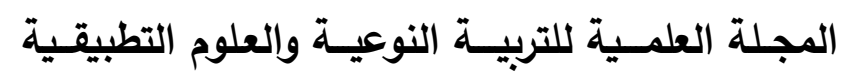

The Scientific Journal of Specific Education and Applied Sciences

Because meat contains a lot of fat and over $40 \%$ is in saturated form, is advisable to modulate its quantity and quality creating new meat products with functional properties (PogorzelskaNowicka et al., 2018). Therefore, current study is trying to enhance $n-6 / n-3$ ratios in meatballs and give acceptable sensory properties by adding green leafy vegetables mixture. In previous studies; Leite et al. (2011) have shown that carrot leaves are a choice of food with high concentration of essential fatty acids PUFA/SFA and n-6/n-3 ratios suitable for human consumption. Boroski et al., (2011) indicated that dried carrot leaves that had substantial amounts of essential fatty acids like $\omega-3$ were used in pasta formulation and this enriched formulation had high levels of LNA and low n6/n-3 ratio. Biondo et al. (2014) reported that both of beetroot and carrot leaves have great amounts of fatty acids; however, beetroot leaves have a 4.7 times higher content of LNA than carrot leaves; Therefore, beetroot leaves can also be used in food formulations to ameliorate its LNA levels. Lee et al. (2009) proposed that the addition of $8 \%$ red beet leaves in high-fat cholesterol diets could stop lipid peroxidation and improve antioxidant defense system in the plasma and tissue of mice.

\section{Nutritional evaluation of prepared meatballs with GLVM}

Data in table (5) presented the nutritional evaluation of prepared meatballs supplemented with GLVM. As the fat content decreased in meatball treatments, total energy (kcal/100g) declined. The meatball control had higher total energy which was $398.13 \mathrm{kcal} / 100 \mathrm{~g}$ in comparison with other treatments. This is because caloric reduction correlated positively with fat reduction. These results are agreement with Kassem and Emara (2010) who established that the highest energy value was in the control burger, while that of vegetable was the lowest. Also, the different levels from GLVM caused a slight decrease in percent of fat calories which recorded $36.22 \%, 35.46 \%, 35.15 \%$ and $34.75 \%$ respectively, as compared to the control sample. It is well known that meat is a good dietary protein source and provides high biological value, as well as fat including saturated fatty acids (SFA), unsaturated fatty acids (USFA), cholesterol, triacylglycerol and phospholipids. Therefore, consumers often relate meat intake with a negative image as a high fat and cancerpromoting food (Valsta et al., 2005). Some of these negative 


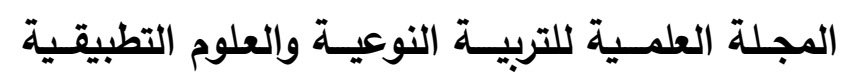

The Scientific Journal of Specific Education and Applied Sciences

nutrients can be reduced by choosing lean meat cuts, eliminating adipose fat, nutritional modification to change the composition of fatty acids and adequate control to limit fat and caloric intake (Hathwar et al., 2012). Due to the decrease in fat content of meatball treatments which prepared by using GLVM the amount of meatballs consumed to cover the daily requirements of both children 11-14 years and adult man 25-50 years in energy (GDR for energy) increased from 650.87 and 755.01 to 728.06 and $844.55 \mathrm{kcal}$ respectively, by increasing percentages of GLVM. It could be noticed that control samples were the lowest consuming amount 627.94 and $728.41 \mathrm{kcal}$ compared with the other samples. In addition, data in the same table revealed that the daily children requirements of protein could be covered when consumed 87.68 to $102.86 \mathrm{~g}$ of prepared meatballs children $11-14$ years. Also, the daily adult man requirements of protein could be covered when consumed 119.07 to $144 \mathrm{~g}$ of prepared meatballs adult man 25-50 years.

\section{Table (5): Nutritional values of prepared meatballs with GLVM}

\begin{tabular}{|c|c|c|c|c|c|c|}
\hline \multirow{2}{*}{\multicolumn{2}{|c|}{ Items }} & \multirow{2}{*}{$\begin{array}{c}\text { Contro } \\
1 \\
0 \%\end{array}$} & \multicolumn{4}{|c|}{ Meatball with GLVM\% } \\
\hline & & & $2.5 \%$ & $5 \%$ & $10 \%$ & $2.5 \%$ \\
\hline \multicolumn{2}{|c|}{ Total energy (Kcal/100g) } & 398.13 & 384.10 & 374.31 & 355.86 & 343.38 \\
\hline \multicolumn{2}{|c|}{$\begin{array}{l}\text { \% Fat calories } \\
\text { (Kcal/100g) }\end{array}$} & 37.55 & 36.22 & 35.46 & 35.15 & 34.75 \\
\hline \multirow{2}{*}{$\begin{array}{l}\text { GDR for } \\
\text { Protein (g) }\end{array}$} & Children & 85.0 & 87.68 & 92.52 & 97.57 & 102.86 \\
\hline & $\begin{array}{c}\text { adult } \\
\text { man }\end{array}$ & 119.07 & 122.76 & 129.52 & 136.60 & 144 \\
\hline \multirow{2}{*}{$\begin{array}{l}\text { GDR for } \\
\text { Energy } \\
\text { (Kcal) }\end{array}$} & Children & 627.94 & 650.87 & 667.90 & 702.50 & 728.06 \\
\hline & $\begin{array}{c}\text { adult } \\
\text { man }\end{array}$ & 728.41 & 755.01 & 774.76 & 814.93 & 844.55 \\
\hline
\end{tabular}

GDR: grams consumed to cover the daily requirements

\section{Cooking properties of prepared meatballs with GLVM}

Table (6) showed the cooking properties of prepared meatballs with green leafy vegetables mixture GLVM. The cooking yield percent in meatball treatment with $2.5 \%$ of GLVM did not differ significantly as compared to the control. On the other hand, the cooking yield \% in meatball samples increased gradually with addition of 5, 10 and 15\% GLVM, they were 


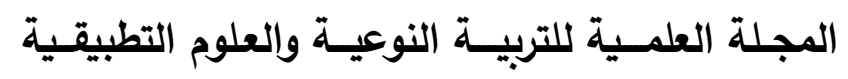

The Scientific Journal of Specific Education and Applied Sciences

recorded $80.53,81.25$ and $82.18 \%$ respectively, as compared to the control sample which recorded 78.50. This is probably due to the ability of green leafy vegetables mixture GLVM to bind more water. In this concern, Bhat and Pathak (2009) and Bhat and Bhat (2011) reported that the fiber is appropriate for addition to meat products and has commonly been used in cooked meat products to increase the cooking yield due to its water-binding and fat-binding properties and to ameliorate texture. Also, Ali et al. (2011) revealed that cooking yield was significantly $(\mathrm{p} \leq 0.05)$ improved by adding various levels of potato flakes. Choe et al. (2019) found that cooking yield of sausages supplemented by green tea leaf and lotus leaf powders did not differ from that of the control. On the other hand, the addition of kimchi in sausage samples resulted in a significant increase in cooking yield.

Table (6): Cooking properties of prepared meatballs
\begin{tabular}{c|c|c|c|c|c} 
with GLVM \\
\hline \multirow{3}{*}{ Parameters } & $\begin{array}{c}\text { Control } \\
\mathbf{0 \%}\end{array}$ & \multicolumn{5}{|c}{ Meatball with GLVM\% } \\
\cline { 3 - 6 } & & $\mathbf{2 . 5 \%}$ & $\mathbf{5 \%}$ & $\mathbf{1 0 \%}$ & $\mathbf{1 5 \%}$ \\
\hline \% Cooking & $78.50^{\mathrm{d}}$ & $79.33^{\mathrm{d}}$ & $80.53^{\mathrm{c}}$ & $81.25^{\mathrm{b}}$ & $82.18^{\mathrm{a}}$ \\
yield & \pm 1.80 & \pm .764 & \pm 1.76 & \pm 1.52 & \pm 1.32 \\
\hline \%Moisture & $12.63^{\mathrm{e}}$ & $13.08^{\mathrm{cd}}$ & $13.62^{\mathrm{c}}$ & $15.51^{\mathrm{b}}$ & $16.18^{\mathrm{a}}$ \\
retention & \pm .294 & \pm .132 & \pm .296 & \pm .290 &. \pm .261 \\
\hline
\end{tabular}

Means with different letter within the same row are significantly different $(\mathrm{P} \leq 0.05)$

Results demonstrated that the moisture retention percent was higher in samples containing GLVM than that of control. The rate of moisture retention increased with increasing the replacement level of GLVM. This result may be due to the high content of fiber in GLVM (table 2) that may be able to hold more water during the cooking process. These results agreement with those of Laban (2004) who found that the addition of pomegranate peels, as a fat replacer at 5,10 and $15 \%$ to prepare low fat burger, resulted in retention of more moisture during cooking due to their ability to bind water. Ali et al. (2011) noticed a significant increases in moisture retention in beef patties formulated with various levels of potato flakes compared with control. Selani et al. (2015) stated that beef burgers formulated with pineapple by-product showed higher moisture retention than 


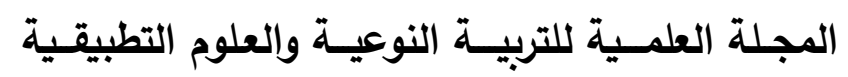

The Scientific Journal of Specific Education and Applied Sciences

traditional treatments, due to the property of the fibers to hold water, resulting in products with higher moisture retention percentages. Also, Khedr et al. (2016) reported similar results: moisture content increased with increasing the replacement level of tomato peels.

\section{Texture profile analysis of prepared meatballs with GLVM}

Textural characteristics play a substantial role in the acceptability of any processed food product. Additionally, processing conditions and ingredient formulations have a direct effect on food products. Choe et al. (2019) reported that the texture properties in meat products are the most important factors indicating their functionality and quality properties. Serdaroğlu et al. (2018) indicated that cooked meat texture is usually regarded to be influenced by modifications in connective tissue, soluble proteins and myofibrillar proteins which caused by heat.

The results of texture profile analysis of meatballs with green leafy vegetables mixture GLVM could be seen in Table (7) and Fig. (1). Hardness values (N) for all samples had increased gradually with increasing amount of GLVM added to be 3.927, 4.443 and 4.887 as compared to the control sample, except the sample containing $2.5 \%$ of GLVM that showed no significant differences with the control. Also, Chewiness values $(\mathrm{mJ})$ for meatball samples were higher than the control and ranged from 1.595 to 2.050 , except the sample with $2.5 \%$ of GLVM which recorded no significant differences with the control. The hardness and chewiness values of meatballs formulated with GLVM were maybe increased with the increasing fiber amount. Similar trends in gumminess was observed, gumminess values $(\mathrm{N})$ of meatballs were significant higher than the control 2.388, 2.746 and 3.206, except the sample treated with $2.5 \%$ of GLVM which was lower than the control. These results are agreement with Yasarlar et al. (2007) who reported that the hardness increased and meatball with $20 \%$ oat bran had highest hardness value. Overall acceptability decreased as bran content increased. Also, Choe et al. (2019) who found that incorporation of the plant powders like green tea leaf, lotus leaf and kimchi showed a significant higher values in hardness, gumminess, and chewiness in sausage samples as compared to the control.

On opposite trend, the same Table (7) and Fig. (1) showed that cohesiveness ratio of meatballs declined with added $2.5 \%$ of 


\section{المجلة العلمـية للتربيـة النوعيـة والعلوم التطبيقـية}

The Scientific Journal of Specific Education and Applied Sciences

GLVM to be 0.595 , while meatballs containing 5 and $10 \%$ of GLVM were higher than the control sample. The sample containing $15 \%$ of GLVM were similar with the control. Concerning of springiness $(\mathrm{mm})$, it could be noticed that springiness values to meatballs containing 2.5 and $5 \%$ of GLVM were higher than the control sample and showed no significant differences between them, while samples containing 10 and $15 \%$ of GLVM were lower than the control. Therefore, it can be said that formulations containing low amount of GLVE $2.5 \%$ and $5 \%$ were more elasticity than formulations containing high amount of GLVE $10 \%$ and $15 \%$.

Table (7): Texture profile analysis of prepared meatballs with GLVM

\begin{tabular}{l|c|c|c|c|c}
\hline \multirow{2}{*}{ Texture parameter } & \multirow{2}{*}{$\begin{array}{c}\text { Control } \\
\text { 0\% }\end{array}$} & \multicolumn{4}{|c}{ Meatball with GLVM\% } \\
\cline { 3 - 6 } & & $\mathbf{2 . 5 \%}$ & $\mathbf{5 \%}$ & $\mathbf{1 0 \%}$ & $\mathbf{1 5 \%}$ \\
\hline \multirow{2}{*}{ hardness (N) } & $2.780^{\mathrm{d}}$ & $2.793^{\mathrm{d}}$ & $3.927^{\mathrm{c}}$ & $4.443^{\mathrm{b}}$ & $4.887^{\mathrm{a}}$ \\
& \pm 0.05 & \pm 0.05 & \pm 0.03 & \pm 0.02 & \pm 0.04 \\
\hline \multirow{2}{*}{ Cohesiveness (ratio) } & $0.656^{\mathrm{c}}$ & $0.595^{\mathrm{d}}$ & $0.608^{\mathrm{b}}$ & $0.618^{\mathrm{a}}$ & $0.656^{\mathrm{c}}$ \\
& \pm 0.01 & \pm 0.05 & \pm 0.02 & \pm 0.04 & \pm 0.04 \\
\hline \multirow{2}{*}{ Gumminess (N) } & $1.820^{\mathrm{d}}$ & $1.674^{\mathrm{e}}$ & $2.388^{\mathrm{c}}$ & $2.746^{\mathrm{b}}$ & $3.206^{\mathrm{a}}$ \\
& \pm 0.02 & \pm 0.06 & \pm 0.05 & \pm 0.03 & \pm 0.05 \\
\hline \multirow{2}{*}{ Chewiness (mJ) } & $1.229^{\mathrm{d}}$ & $1.132^{\mathrm{de}}$ & $1.633^{\mathrm{c}}$ & $1.798^{\mathrm{b}}$ & $2.122^{\mathrm{a}}$ \\
& \pm 0.05 & \pm 0.06 & \pm 0.02 & \pm 0.03 & \pm 0.03 \\
\hline \multirow{2}{*}{ Springiness (mm) } & $0.674^{\mathrm{b}}$ & $0.681^{\mathrm{a}}$ & $0.684^{\mathrm{a}}$ & $0.655^{\mathrm{cd}}$ & $0.662^{\mathrm{c}}$ \\
& \pm 0.19 & \pm 0.09 & \pm 0.11 & \pm 0.07 & \pm 0.08 \\
\hline
\end{tabular}

Means with different letter within the same row are significantly different $(\mathrm{P} \leq 0.05)$

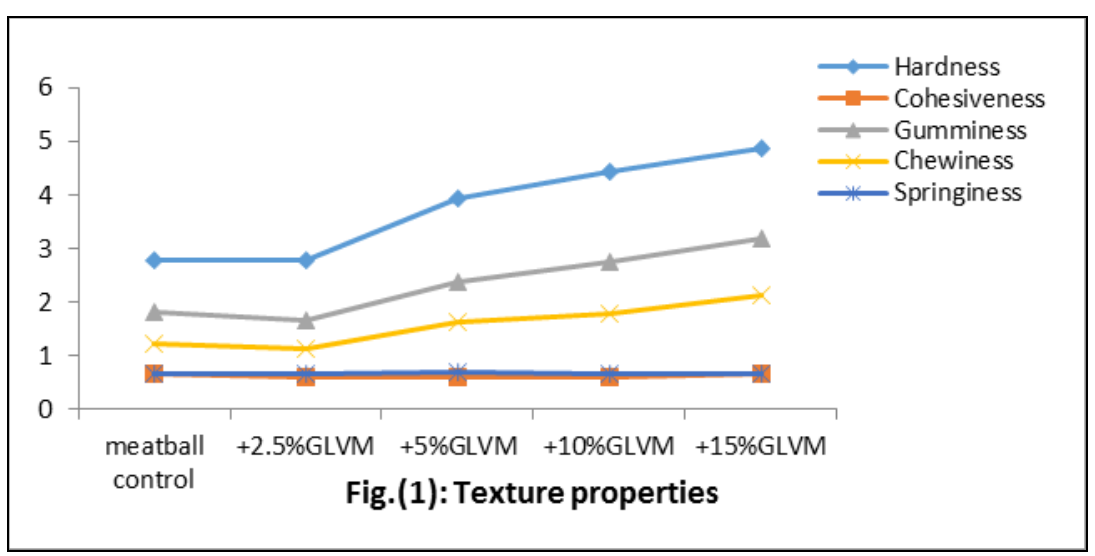




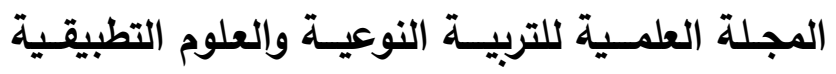

The Scientific Journal of Specific Education and Applied Sciences

\section{Sensory properties of prepared meatballs with GLVM}

Sensory evaluation is a crucial indicator of potential consumer preferences. Table (8) presented the sensory characteristics of prepared meatballs with green leafy vegetables mixture GLVM. Form statistical analysis presented in the table, it could be observed that most formulations were acceptable in all sensory evaluation attributes (color, taste, flavor, texture and general acceptability) and no significant differences $(P<0.05)$ between the samples supplemented with 2.5 and 5\% of GLVE when compared with control sample. While substitution with high levels from GLVE by 10 and $15 \%$ caused a significant differences $(P<0.05)$ in the same sensory evaluation attributes as compared to the control sample. Although results observed that meatball sample containing of 15\% GLVE received the highest hardness score that cause in a decrease the overall acceptability, but the results of acceptance test showed that consumers like all most samples; general acceptance score ranged from 8.23 to 6.61 . It means that green leafy vegetable mixture can be used in the preparation of meatballs. These results are agreement with Gedikoğlu and Clarke (2019) who found that over all likeness was highest for control followed by citrus fiber with different levels $1 \%, 3 \%$ and 5\% respectively. Also, results are in line with El-Nashi et al., (2015) who noticed that addition of pomegranate peels powder had a significant effect on improving the sensory characteristics of prepared beef burger samples and increased their acceptability during storage.

Table (8): Sensory characteristics of prepared meatballs with GLVM

\begin{tabular}{l|c|c|c|c|c}
\hline \multirow{2}{*}{$\begin{array}{c}\text { Sensory } \\
\text { Characteristi } \\
\text { cs }\end{array}$} & \multirow{2}{*}{$\begin{array}{c}\text { Control } \\
\mathbf{0 \%}\end{array}$} & \multicolumn{4}{|c}{ Meatball with GLVM\% } \\
\cline { 3 - 6 } & & $\mathbf{2 . 5 \%}$ & $\mathbf{5 \%}$ & $\mathbf{1 0 \%}$ & $\mathbf{1 5 \%}$ \\
\hline \multirow{2}{*}{ Color } & $8.48^{\mathrm{a}}$ & $8.60^{\mathrm{a}}$ & $8.50^{\mathrm{a}}$ & $8.01^{\mathrm{b}}$ & $7.03^{\mathrm{c}}$ \\
& \pm .291 & \pm .376 & \pm .359 & \pm .782 & \pm .446 \\
\hline \multirow{2}{*}{ Taste } & $8.74^{\mathrm{a}}$ & $8.59^{\mathrm{ab}}$ & $8.58^{\mathrm{ab}}$ & $8.16^{\mathrm{b}}$ & $7.02^{\mathrm{c}}$ \\
& \pm .283 & \pm .303 & \pm .379 & \pm .832 & \pm .487 \\
\hline \multirow{2}{*}{ Flavor } & $8.83^{\mathrm{a}}$ & $8.64^{\mathrm{ab}}$ & $8.12^{\mathrm{bc}}$ & $7.69^{\mathrm{c}}$ & $6.95^{\mathrm{d}}$ \\
& \pm .346 & \pm .374 & \pm .714 & \pm .458 & \pm .466 \\
\hline \multirow{2}{*}{ Texture } & $8.38^{\mathrm{a}}$ & $8.19^{\mathrm{a}}$ & $8.07^{\mathrm{a}}$ & $7.32^{\mathrm{b}}$ & $6.63^{\mathrm{c}}$ \\
& \pm .498 & \pm .314 & \pm .392 & \pm .559 & \pm .363 \\
\hline General & $8.65^{\mathrm{a}}$ & $8.23^{\mathrm{a}}$ & $8.17^{\mathrm{ab}}$ & $7.11^{\mathrm{b}}$ & $6.61^{\mathrm{c}}$ \\
Acceptance & \pm .411 & \pm .612 & \pm .674 & \pm .443 & \pm .384 \\
\hline
\end{tabular}

Means with different letter within the same row are significantly different $(\mathrm{P} \leq 0.05)$ 


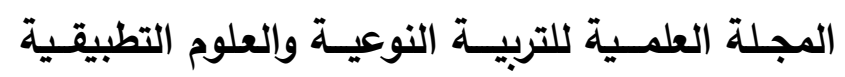

The Scientific Journal of Specific Education and Applied Sciences

\section{In conclusion}

In conclusion, current study has presented the possibility of developing meat products by using green leafy vegetables from turnip, beet root and carrot up to $10 \%$ level. Moreover, the study showed that consumers could accept the new product and green leafy vegetables mixture is suitable for meatballs preparation, in result to acquire new taste nuances of meatballs. Also, the study care about using the low-cost material which have high nutritional value to reduce the environmental impact of discarding.

\section{References}

A.O.A.C. (2000): Official methods of analysis (17th ed.). Washington, DC: Association of Official Analytical Chemists.

A.O.A.C. (2016): Official methods of analysis. (20th ed.). Washington, DC: Association of Analytical Chemists.

Ajila C. M. and Prasada Rao U. J. S. (2013): Mango peel dietary fiber: composition and associated bound phenolics. J Funct Foods 5:444-50.

Ali, R. F., El-Anany, A. M. and Gaafar, A. M. (2011): Effect of potato flakes as fat replacer on the quality attributes of low-fat beef patties. Advance Journal of Food Science and Technology, 3(3), 173-180.

Anderson, J.W.; Baird, P.; Davis, R.H., Jr.; Ferreri, S.; Knudtson, M.; Koraym, A.;Waters, V. and Williams, C.L. (2009): Health benefits of dietary fiber. Nutr. Rev., 67, 188-205.

Armitage, P. and Berry, G. (1987): Statistical Method in Medical Research". Blackwell, Oxford, UK, pp . 93-213.

Artemyeva, A. M., Solovyeva, A. E. and Vavilov, N. I. (2006): Quality evaluation of some cultivar types of leafy Brassica rapa. Acta Horticulturae, 706, 121:128.

Berdja, S., Smail, L., Saka, B., Neggazi, S., Haffaf, E. M., Benazzoug, Y. and Aouichat Bouguerra, S. (2016): Glucotoxicity induced oxidative stress and inflammation in vivo and in vitro in Psammomys obesus: involvement of aqueous extract of Brassica rapa rapifera. EvidenceBased Complementary and Alternative Medicine. 


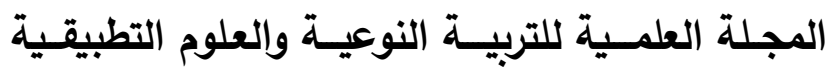

The Scientific Journal of Specific Education and Applied Sciences

Beriain, M. J., Gómez, I., Ibáñez, F. C., Sarriés, M. V. and Ordóñez, A. I. (2018): Improvement of the functional and healthy properties of meat products. In Food quality: Balancing health and disease (pp.1-74). Academic Press.

Bessar, B. A. (2008): Effect of using orange and apple peel as fat replacers on the sensory, physical and nutritional evaluation of beef burgers. J. Agric. Res. Kafr El-Sheikh Univ., 34 (4): 1035-1056.

Bhat, Z.F. and V. Pathak (2009): Effect of Mung bean (Vigna radiata) on quality characteristicsof oven roasted chicken seekh kababs. Fleischwirtschaft International., 6, 58-60.

Bhat, Z.F. and H. Bhat, (2011): Animal-Free Meat Biofabrication. American Journal of Food.Technology, 6 (6): 441-459.

Biondo, P. B. F., Boeing, J. S., Barizão, É. O., Souza, N. E. D., Matsushita, M., Oliveira, C. C. D. and Visentainer, J. V. (2014): Evaluation of beetroot (Beta vulgaris L.) leaves during its developmental stages: a chemical composition study. Food Science and Technology, 34(1), 94-101.

Biswas, A. K., Kumar, V., Bhosle, S., Sahoo, J. and Chatli, M. K. (2011): Dietary fibers as functional ingredients in meat products and their role in human health. International Journal of Livestock Production, 2(4), 45-54.

Boroski, M., de Aguiar, A. C., Boeing, J. S., Rotta, E. M., Wibby, C. L., Bonafé, E. G. and Visentainer, J. V. (2011): Enhancement of pasta antioxidant activity with oregano and carrot leaf. Food chemistry, 125(2), 696700.

Bourne, M.C. (2003): food texture and viscosity: concept measurement. Elsevier press, New York / London.

Choe, J., Kim, G. W. and Kim, H. Y. (2019): Effects of green tea leaf, lotus leaf, and kimchi powders on quality characteristics of chicken liver sausages. Journal of Animal Science and Technology, 61(1), 28-34.

Edelman, M. and Colt, M. (2016): Nutrient value of leaf vs. seed. Frontiers in chemistry, 4, 32.

Ekholm, P., Reinivuo, H., Mattila, P., Pakkala, H., Koponen, J., Happonen, A., Hellström, J. and Ovaskainen, M. 


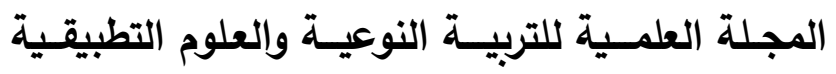

The Scientific Journal of Specific Education and Applied Sciences

L. (2007): Changes in the mineral and trace element contents of cereal, fruits and vegetables in Finland. Journal of Food Composition and Analysis, 20(6), 487495.

El-Beltagi, H. S., Mohamed, H. I., Megahed, B. M., Gamal, M. and Safwat, G. (2018): Evaluation of some chemical constituents, antioxidant, antibacterial and anticancer activities of Beta vulgaris L. root. Fresenius Environmental Bulletin, 27(9), 6369-6378.

El-Magoli, S. B., Laroia, S. and Hansen, P. T. M. (1996): Flavor and texture characteristics of low fat ground beef patties formula with whey protein concentrate. Meat Science 42 (2): 179-193.

El-Nashi, H. B., Fattah, A. F. A. K. A., Rahman, N. R. A. and El-Razik, M. A. (2015): Quality characteristics of beef sausage containing pomegranate peels during refrigerated storage. Annals of Agricultural Sciences, 60(2), 403-412.

El-Shehawy, Sh. M., Goneim, Gehan A. and Ibrahim, Faten Y. (2011): Carrot leaves: antioxidative and nutritive values. Food Industries Dept., Faculty of Agriculture, Mansoura University, Egypt.

Elzebroek, T. and Wind, K. (2008): Guide to cultivated plants. Wallingford, CABI Publ. 540 pp.

FAO/WHO/UNU (1985). Energy and Protein Requirements Report of Joint FAO/WHO/UNU Expert Consultation World Health Organization, Technical Report, Series 724, WHO, Geneva.

Fard, M. H., Naseh, G., Lotfi, N., Hosseini, S. M. and Hosseini, M. (2015): Effects of aqueous extract of turnip leaf (Brassica rapa) in alloxan-induced diabetic rats. Avicenna journal of phytomedicine, 5(2), 148.

Farvin, K. S., Grejsen, H. D. and Jacobsen, C. (2012): Potato peel extract as a natural antioxidant in chilled storage of minced horse mackerel (Trachurus trachurus): Effect on lipid and protein oxidation. Food Chemistry, 131(3), 843851.

Fernandes, F., Valentão, P., Sousa, C., Pereira, J. A., Seabra, R. M. and Andrade, P. B. (2007): Chemical and antioxidative assessment of dietary turnip (Brassica rapa var. rapa L.). Food Chemistry, 105(3), 1003-1010. 


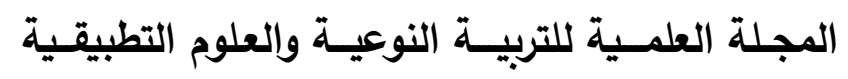

The Scientific Journal of Specific Education and Applied Sciences

Fernández, M. V., Jagus, R. and Agüero, M. (2017): Evaluation and characterization of nutritional, microbiological and sensory properties of beet greens. Acta Scientific Nutritional Health, 1(3), 37-45.

Gedikoğlu, A. and Clarke, A. D. (2019): Quality attributes of citrus fiber added ground beef and consumer acceptance of citrus fiber added Turkish meatballs. Food and health, 5(4), 205-214.

Gennari, L., Felletti, M., Blasa, M., Angelino, D., Celeghini, C., Corallini, A. and Ninfali, P. (2011): Total extract of Beta vulgaris var. cicla seeds versus its purified phenolic components: antioxidant activities and antiproliferative effects against colon cancer cells. Phytochemical Analysis, 22(3), 272-279.

Goby, J. P. and Gidenne, T. (2008): Nutritive value of carrot (whole plant), dried at low temperature, for the growing rabbit. In Proc. 9th World Rabbit Congress, Verona, Italy (pp. 10-13).

Guldiken, B., Toydemir, G., Nur Memis, K., Okur, S., Boyacioglu, D. and Capanoglu, E. (2016): Homeprocessed red beetroot (Beta vulgaris L.) products: changes in antioxidant properties and bioaccessibility. Int. J. Mol. Sci. 17, 858.

Habegger, R. \& Schnitzler, W. H. (2000): Aroma compounds in the essential oil of carrot (Daucus carota L. spp. sativus). 2. Intra leaf distribution. J. Appl. Bot.74, 229232.

Hathwar, S. C., Rai, A. K., Modi, V. K. and Narayan, B. (2012): Characteristics and consumer acceptance of healthier meat and meat product formulations-a review. Journal of food science and technology, 49(6), 653-664.

Hur, S. J., Lim, B. O., Park, G. B., and Joo, S. T. (2009): Effects of various fiber additions on lipid digestion during in vitro digestion of beef patties. Journal of food science, 74(9), C653-C657.

Institute of Food Technologists IFT (1981): Sensory evaluation guide for testing food and beverage products. Journal of Food Science, 11, 50-59. 


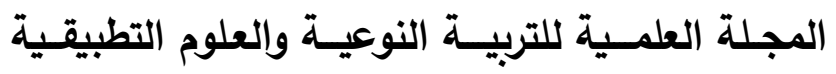

The Scientific Journal of Specific Education and Applied Sciences

Kabir, F., Tow, W. W., Hamauzu, Y., Katayama, S., Tanaka, S. and Nakamura, S. (2015): Antioxidant and cytoprotective activities of extracts prepared from fruit and vegetable wastes and by-products. Food chemistry, 167, 358-362.

Kapadia, G. J. and Rao, G. S. (2013): Anticancer effects of red beet pigments. In Red Beet Biotechnology (pp. 125-154). Springer, Boston, MA.

Kassem, G.M.A. and Emara M.M.T. (2010): Quality and Acceptability of Value-Added Beef Burger. World Journal of Dairy \& Food Sciences 5 (1): 14-20, 2010.

Kawashima, L. M. and Soares, L. M. V. (2003): Mineral profile of raw and cooked leafy vegetables consumed in Southern Brazil. Journal of Food Composition and Analysis, 16(5), 605-61.

Khedr M. A., Abdelgaleel M. A., Bessar B. A. and Salama A. A. (2016): Effect of using tomato peels as a fat replacer on the sensory, nutritional and physical properties of beef burger and sausages. J. Agric. Res. Kafr El-Sheikh Univ., Vol. 42(1) pp: 469-490.

Kim, S. J., Cho, A. R. and Han, J. (2013): Antioxidant and antimicrobial activities of leafy green vegetable extracts and their applications to meat product preservation. Food control, 29(1), 112-120.

Kumar, B. R. (2017): Application of HPLC and ESI-MS techniques in the analysis of phenolic acids and flavonoids from green leafy vegetables (GLVs). Journal of pharmaceutical analysis, 7(6), 349-364.

Kumar, V., Kumar Biswas, A., Kumar Chatli, M. and Sahoo, J. (2011): Effect of banana and soybean hull flours on vacuum-packaged chicken nuggets during refrigeration storage. International journal of food science \& technology, 46(1), 122-129.

Laban, S. M. (2004): Pomegranate peels as a potential source of dietary fibers and natural antioxidants. Egypt. J. Agric. Res., 82 (3): 273- 290.

Lee, J. H., Son, C. W., Kim, M. Y., Kim, M. H., Kim, H. R., Kwak, E. S. and Kim, M. R. (2009): Red beet (Beta vulgaris L.) leaf supplementation improves antioxidant 


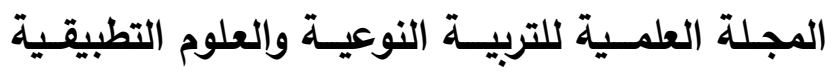

The Scientific Journal of Specific Education and Applied Sciences

status in C57BL/6J mice fed high fat high cholesterol diet. Nutrition research and practice, 3(2), 114-121.

Leite, C. W., Boroski, M., Boeing, J. S., Aguiar, A. C., França, P. B., Souza, N. E. D. and Visentainer, J. V. (2011): Chemical characterization of leaves of organically grown carrot Dacus carota L.) in various stages of development for use as food. Food Science and Technology, 31(3), 735-738.

Leong, H. Y., Show, P. L., Lim, M. H., Ooi, C. W. and Ling, T. C. (2018): Natural red pigments from plants and their health benefits: A review. Food reviews international, 34(5), 463-482.

Liang, Y. S., Kim, H. K., Lefeber, A. W. M., Erkelens, C., Choi, Y. H. and Verpoorte, R. (2006): Identification of phenylpropanoids in methyl jasmonate treated Brassica rapa leaves using two-dimensional nuclear magnetic resonance spectroscopy. Journal of Chromatography A, 1112(1-2), 148-155.

Lim, S. S., Jung, Y. J., Hyun, S. K., Lee, Y. S. and Choi, J. S. (2006): Rat lens aldose reductase inhibitory constituents of Nelumbo nucifera stamens. Phytotherapy Research: An International Journal Devoted to Pharmacological and Toxicological Evaluation of Natural Product Derivatives, 20(10), 825-830.

Mozaffarian, D.; Micha, R. and Wallace, S. (2010): Effects on Coronary Heart Disease of Increasing Polyunsaturated Fat in Place of Saturated Fat: A Systematic Review and Meta-Analysis of Randomized Controlled Trials.

National Research Council NRC (1989): Recommended dietary allowances. National Academies Press.

Neelwarne, B. and Halagur, S.B. (2012): Red beet: an overview. In: Red Beet Biotechnology: Food and Pharmaceutical Applications. Neel-warne, B. (Ed.), New York: Springer, 1-43.

Ninfali, P., Bacchiocca, M., Antonelli, A., Biagiotti, E., Gioacchino, A.M., Piccoli, G., Stocchi V. and Brandi. G. (2007): Characterization and biological activity of main fl avonoids from Swiss chard (Beta vulgaris subspecies cycla). Phytomedicine 14: 216-221. 


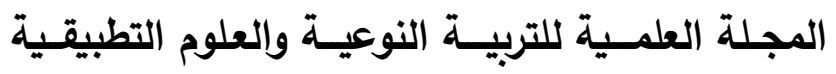

The Scientific Journal of Specific Education and Applied Sciences

O'Shea, N., Arendt, E. K. and Gallagher, E. (2012): Dietary fiber and phytochemical characteristics of fruit and vegetable by-products and their recent applications as novel ingredients in food products. Innovative Food Science \& Emerging Technologies, 16, 1-10.

Pogorzelska-Nowicka, E., Atanasov, A., Horbańczuk, J. and Wierzbicka, A. (2018): Bioactive compounds in functional meat products. Molecules, 23(2), 307.

Reddy, D. M., Reddy, G. V. B. and Mandal, P. K. (2018): Application of Natural Antioxidants in Meat and Meat Products-A Review. Food Nutr J: FDNJ-173. DOI, 10, 2575-7091.

Romani, A., Vignolini, P., Isolani, L., Ieri, F. and Heimler, D. (2006): HPLC-DAD/MS characterization of flavonoids and hydroxycinnamic derivatives in turnip tops (Brassica rapa L. subsp. sylvestris L.). Journal of Agricultural and Food Chemistry, 54(4), 1342-1346.

Sagar, N. A., Pareek, S., Sharma, S., Yahia, E. M. and Lobo, M. G. (2018): Fruit and vegetable waste: Bioactive compounds, their extraction, and possible utilization. Comprehensive Reviews in Food Science and Food Safety, 17(3), 512-531.

Selani, M. M., Margiotta, G. B., Piedade, S. M. S., ContrerasCastillo, C. J. and Canniatti-Brazaca, S. G. (2015): Physicochemical, sensory and cooking properties of low fat beef burgers with addition of fruit byproducts and canola oil. Int Proc Chem Biol Environ Eng, 81, 58-65.

Serdaroglu, M. (2006): Improving low fat meat balls characteristics by adding whey powder. Meat Science 72: 155-163.

Serdaroğlu, M., Kavuşan, H. S., İpek, G. and Öztürk, B. (2018): Evaluation of the quality of beef patties formulated with dried pumpkin pulp and seed. Korean journal for food science of animal resources, 38(1), 1.

Simopoulos, A. P. (2006): Evolutionary aspects of diet, the omega-6/omega-3 ratio and genetic variation: nutritional implications for chronic diseases. Biomedicine \& pharmacotherapy, 60(9), 502-507.

Stephen, A. and Suresh, R. (2015): Nutritive and therapeutic values of vegetables from the markets of Chennai, Tamil 


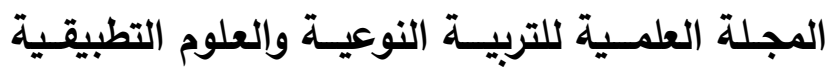

The Scientific Journal of Specific Education and Applied Sciences

Nadu, India. Journal of Academia and Industrial Research (JAIR), 3(11), 546.

Surbhi, S., Verma, R. C., Deepak, R., Jain, H. K. and Yadav, K. K. (2018): A review: food, chemical composition and utilization of carrot (Daucus carota L.) pomace. IJCS, 6(3), 2921-2926.

Valsta, L. M., Tapanainen, H. and Männistö, S. (2005): Meat fats in nutrition. Meat science, 70(3), 525-530.

Walsh, R. P., Bartlett, H. and Eperjesi, F. (2015): Variation in carotenoid content of kale and other vegetables: A review of pre-and post-harvest effects. Journal of agricultural and food chemistry, 63(44), 9677-9682.

Wang, D. D. and Hu, F. B. (2017): Dietary fat and risk of cardiovascular disease: recent controversies and advances. Annual review of nutrition, 37, 423-446.

Yasarlar, E. E., Daglioglu, O. and Yilmaz, I. (2007): Effects of Cereal Bran Addition on Chemical Composition, Cooking Characteristics and Sensory Properties of Turkish Meatballs. Asian Journal of Chemistry, 19(3), 2353.

Yilmaz, I. and Daglioglu, O. (2003): The Effect of replacing fat with oat bran on fatty acid composition and physicochemical properties of meatballs. Meat Sci. 65:819-823.

Yilmaz, I. (2004): Effects of rye bran addition on fatty acid composition and quality characteristics of low fat meat balls. Meat Sci. 67:245-249.

Yilmaz, I. (2005): Physicochemical and sensory characteristics of low fat meat balls with added wheat bran. J. Food Eng. 69:369-373. 


\section{المجلة العلمـية للتربيـة النوعيـة والعلوم التطبيقـية}

\section{The Scientific Journal of Specific Education and Applied Sciences}

\section{تأثير إضافة بعض أوراق الخضروات الخضراء قليلة الاستخدام على الخي

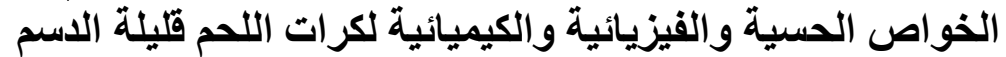 رشا محمود عرفه ولهية}

قسم الاقتصاد المنزلي ـ كلية التربية النوعية ـ جامعة دمياط

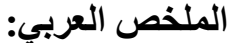

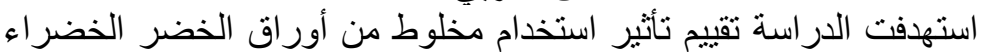

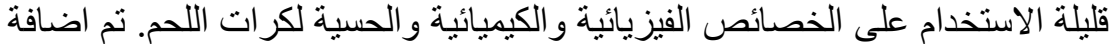

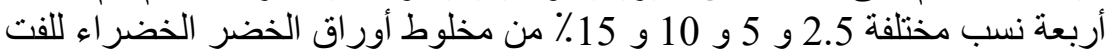
و البنجر و الجزر كبديل لدهون اللحم. و وأسفرت نتائج التركيب الكيميائي لمخلوط

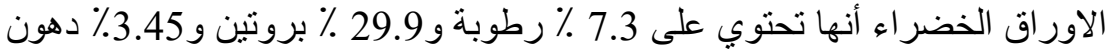

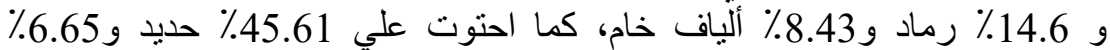

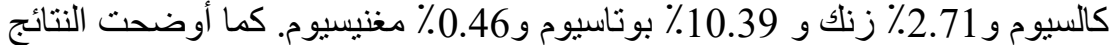

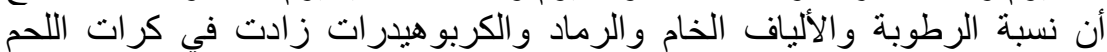

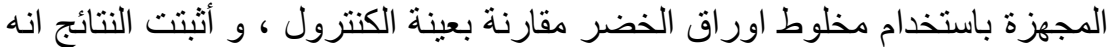

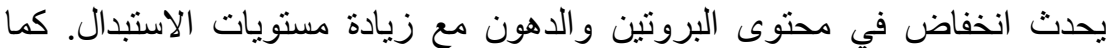

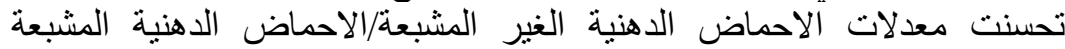
(USFAs/SFAs)

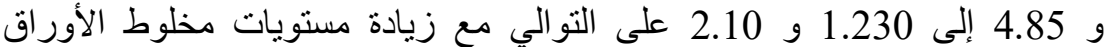

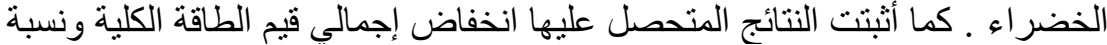

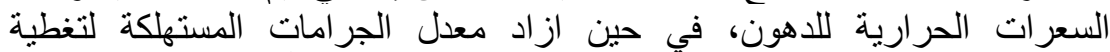

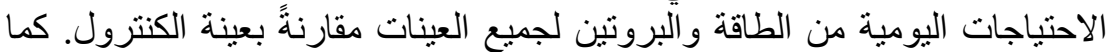

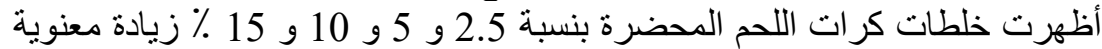

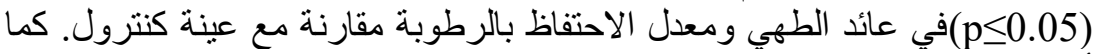

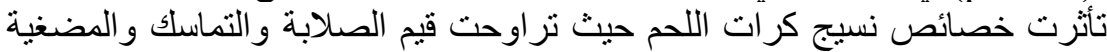

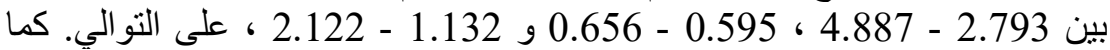

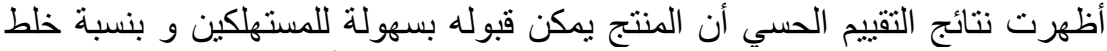

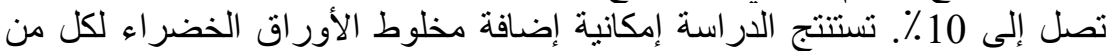

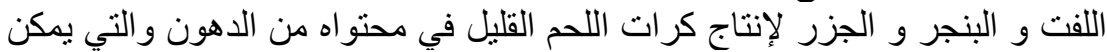
ان تحد من الاصابة بأمر اض القلب وتصلب الثرا الثراين.

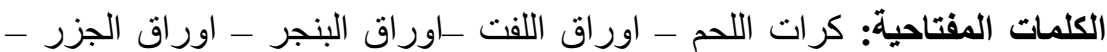
الأحماض الدهنية ـ الخصائص الحسية ـ ـ عائد الطهي. 